\title{
Program Kemitraan Upaya Pemberdayaan UMKM Di Masa Pandemi COVID-19 (Studi Kasus : PT. Jasa Marga Surabaya Gempol)
}

\author{
Esprita Novry Firstyananda ${ }^{1}$, Khairunnisa Putri Rahma ${ }^{2}$, Susi Hardjati ${ }^{3}$ \\ ${ }^{123}$ Jurusan Administrasi Publik, Universitas Pembangunan Nasional "Veteran" Jawa Timur \\ email : susi hardjati.adneg@upnjatim.ac.id
}

\begin{abstract}
Abstrak
Usaha Mikro, Kecil dan Menengah (UMKM) merupakan sektor yang sangat terpuruk akibat adanya pandemi Covid-19. Di Indonesia UMKM memiliki peranan penting dan strategis dalam pertumbungan ekonomi nasional. Perusahaan BUMN seperti PT. Jasa Marga Surabaya Gempol ikut berkontribusi dalam tanggung jawab sosial perusahaan. Salah satunya adalah program kemitraan yang memberikan bantuan permodalan dan pembinaan kepada UMKM. Maka dalam penelitian ini memiliki tujuan untuk mengetahui pelaksanaan program kemitraan pada PT Jasa Marga Surabaya Gempol dan untuk mengetahui upaya kontribusi PT Jasa Marga Surabaya Gempol dalam pemberdayaan UMKM di masa pandemi Covid-19. Penelitian ini menggunakan metode penelitian deskriptif dengan pendekatan kualitatif. Data yang digunakan dalam penelitian ini berupa data primer yang bersumber langsung dari informan dengan melakukan wawancara. Hasil penelitian ini menunjukkan PT Jasa Marga Surabaya Gempol sebagai penyelenggara program kemitraan sudah cukup baik. Salah satu kontribusi PT. Jasa Marga Surabaya Gempol terhadap UMKM di masa pandemi Covid-19 yaitu mengikutkanserta mitra binaanya untuk mengikuti pameran INAPRO EXPO 2020 dan berhasil mendapatkan penghargaan. Akan tetapi, pelaksanaan Program Kemitraan juga mempunyai hambatan dalam praktek kegiatannya yaitu adanya tunggakan atas kewajiban dari mitra binaan.
\end{abstract}

Kata Kunci : Program Kemitraan,Tanggung Jawab Sosial,UMKM

\section{PENDAHULUAN}

Pada saat ini Indonesia sedang dihadapkan oleh adanya pandemi virus Covid-19. Virus ini bisa menjadi ancaman yang serius yang dapat mempengaruhi stabilitas suatu negara. Pandemi ini menyebabkan sebagian besar aktivitas manusia berbeda dari sebelumnya, hal ini menyebabkan pemerintah mengeluarkan kebijakan-kebijakan baru seperti Work From Home (WFH), Pembelajaran Jarak Jauh (PJJ), social distancing, 3M (mencuci tangan, memakai masker, dan menjaga jarak), dan kebijakankebijakan lainnya baik dalam skala lokal maupun nasional. Kebijakan-kebijakan baru tersebut tentunya memberi dampak yang cukup signifikan terhadap seluruh aspek kehidupan, tidak hanya berpengaruh terhadap segi kesehatan saja melainkan juga berpengaruh pada segi pendidikan, pariwisata, sosial, dan juga ekonomi. Pada segi ekonomi tentunya banyak mengalami penurunan pemasukan termasuk perusahaan besar sekalipun, yang menyebabkan pemutusan hubungan kerja (PHK) kepada para karyawannya. Kondisi ini tentu juga berpengaruh terhadap lemahnya daya beli masyarakat karena salah satu syarat pasar yang sukses yaitu dapat menciptakan daya beli yang tinggi. Pandemi Covid-19 ini juga masih belum diketahui kapan akan berakhir, hal ini tentu saja memicu ketidakpastian sehingga investasi juga ikut melemah.

Salah satu sektor yang sangat terdampak oleh adanya pandemi Covid-19 adalah Usaha Mikro, Kecil, dan Menengah (UMKM) yang juga mempengaruhi turunnya perekonomian nasional. Rerata mereka mengalami penurunan omzet, kerugian, hingga sebagian harus tutup karena sepinya permintaan pasar, hal itu di buktikan dengan adanya hasil survei Badan Pusat Statistik (BPS) yang menunjukan penjualan sektor UMKM mengalami penurunan hingga $90 \%$ (www.kompasiana, 2020).

Mengingat di Indonesia, UMKM memiliki peran yang penting dan strategis dalam 
pertumbuhan ekonomi nasional, dengan adanya kewirausahaan ini dapat mendorong kemajuan ekonomi di Indonesia (Nurhartanti, 2019). Maka perlu pemberdayaan UMKM untuk dijadikan prioritas sebab dengan adanya sektor ini dapat mengurangi tingkat pengangguran dan mempertahankan serta dapat meningkatkan pembentukkan produk domestik bruto (Ahmadun, 2015). Menurut data Kementerian Koperasi, Usaha Kecil, dan Menengah (KUKM) tahun 2018, Daya serap tenaga kerja UMKM adalah sebanyak 97\% dari daya serap tenaga kerja dunia usaha. Sementara itu kontribusi UMKM terhadap produk domestik bruoto sebesar 61,1\%, (www.djkn.kemenkeu.go.id, 2020)

Program Tanggung Jawab Sosial Perusahaan atau Corporate Social Responsibility (CSR) adalah salah satu bentuk perhatian suatu perusahaan untuk membantu masyarakat di sekitar lingkungan perusahaan yang bertujuan untuk membantu dan mensejahterakan kehidupan serta akan mendatangkan profit bagi perusahaan, dan dana yang digunakan didapat dari penyisihan laba perusahaan (Wilyandri, 2017). Menurut pakar pemasaran Philip Kotler bersama Nancy Lee mendefinisikan tanggung jawab sosial sebagai perusahaan yang melakukan pergerakan untuk memperbaiki kesejahteraan suatu komunitas dengan cara melakukan praktikpraktik kebijakan bisnis dan juga adanya keterlibatan dari perusahaan. Program ini tentu juga memiliki manfaat salah satunya yaitu untuk mempertinggi reputasi dan Corporate branding, yang berarti jika suatu perusahaan menjalankan tanggung jawab sosial perusahaan maka perusahaan tersebut telah menjalankan salah satu kewajiban yang tertulis pada Undang-Undang No. 25 Tahun 2007 tentang Penanaman Modal dan Undang-Undang No. 40 Tahun 2007 tentang Perseroan Terbatas yang berisi setiap penanam modal atau perusahaan yang menjalankan usaha di bidang dan/atau bersangkutan dengan sumber daya alam wajib menjalankan tanggung jawab sosial perusahaan (Surnaryo, 2015).

PT. Jasa Marga Surabaya Gempol sebagai operator jalan tol, ikut berkontribusi dalam tanggung jawab sosial perusahaan salah satunya adalah program kemitraan yaitu memberikan bantuan permodalan dan pembinaan kepada UMKM. Dengan adanya program kemitraan juga merupakan solusi untuk menyelesaikan permasalahan yang ada yaitu kurangnya permodalan sebagai masalah utama dalam pengelolaam usaha pada UMKM, biasanya terjadi karena modal yang bersifat pribadi dan terbatas dan sedikitnya akses pada lembaga keuangan. Permasalahan lainnya juga terjadi pada UMKM yaitu rendahnya penggunaan teknologi dan kualitas SDM sehingga menghambat peningkatan produktivitas (Diana, 2019).

Tidak hanya memberikan bantuan permodalan, program kemitraan juga bertanggung jawab melakukan pembinaan untuk mengetahui perkembangan usaha mitra binaan yang dilakukan oleh unit Community Development berupa pelatihan dan pemasaran, seperti pelatihan cara mendesain kemasan yang baik sampai mengajarkan tips pemasaran produk melalui online yang bertujuan untuk membuat inovasi terhadap usaha mereka. Unit Community Development juga beberapa kali mengikutsertakan mitra binaan dalam beberapa pameran baik skala nasional maupun internasional.

Dari uraian diatas, penulis menetapkan batasan masalah sebagai berikut 1) bagaimana pemberdayaan UMKM melalui program kemitraan yang dilakukan oleh PT Jasa Marga Surabaya Gempol, 2) bagaimana upaya kontribusi PT Jasa Marga Surabaya Gempol pada UMKM di masa pandemi Covid-19. Tujuan penulisan adalah untuk mengetahui pelaksanaan pemberdayaan UMKM melalui program kemitraan dan upaya kontribusi di masa pandemi Covid-19 yang dilaksanakan PT Jasa Marga Surabaya Gempol.

\section{METODE PENELITIAN}

Dalam penelitian ini menggunakan metode penelitian deskriptif dengan pendekatan kualitatif yang khusunya merupakan metode penelitian di bidang sosial. Menurut Muhadjir dalam (Nugrahani, 2014) metode penelitian dekriptif kualitatif, memiliki karakter yang salah satunya merupakan dokumentasi terstruktur tentang pelaksanaan program, yang dapat digunakan untuk landasan pengembangan teori secara induktif. Difokuskan pada studi kasus dengan menganalisis fenomena sosial pelaksanaan program kemitraan untuk pemberdayaan ekonomi UMKM dan kontribusi perusahaan pada UMKM di masa pandemi Covid19 yang dilakukan PT Jasa Marga Surabaya Gempol. 
Adapun data yang digunakan dalam penelitian ini adalah berupa data primer yaitu yang bersumber langsung dari informan dengan melakukan wawancara kepada unit Community Development yang mengelola program kemitraan dan bina lingkungan. Sedangkan data sekunder diambil dari dokumen-dokumen yang yang terkait dengan realisasi program kemitraan periode 2017 - 2020 serta buku-buku referensi dan artikelartikel yang terkait dengan penelitian ini.

\section{PEMBAHASAN}

\subsection{Pemberdayaan UMKM Melalui Program} Kemitraan Pada PT Jasa Marga Surabaya Gempol Menurut Mubyarto dalam (Sunariani, 2017) pemberdayaan merupakan cara untuk membangun masyarakat agar terdorong, termotivasi dan menumbuhkan kesadaran akan potensi yang dimiliki serta cara untuk mengembangkannya. Pemberdayaan UMKM berdasarkan UU No. 20 Tahun 2008 merupakan "Upaya yang dilakukan Pemerintah, Pemerintah Daerah, Dunia Usaha, dan masyarakat secara sinergis dalam bentuk penumbuhan iklim dan pengembangan usaha terhadap Usaha Mikro, Kecil, dan Menengah sehingga mampu tumbuh dan berkembang menjadi usaha yang tangguh dan mandiri". Pengembangan UMKM perlu dukungan dari berbagai pihak mengingat perannya yang sangat besar dalam kontribusi pada perekonomian nasional.

Bentuk pemberdayaan UMKM yang dilakukan BUMN merupakan tanggung jawab sosial yang tertera dalam UU No.40 Tahun 2007 Pasal 1 Ayat 3 yang berbunyi "Tanggung Jawab Sosial dan Lingkungan adalah komitmen Perseroan untuk berperan serta dalam pembangunan ekonomi berkelanjutan guna meningkatkan kualitas kehidupan dan lingkungan yang bermanfaat, baik bagi Perseroan sendiri, komunitas setempat, maupun masyarakat pada umumnya", salah satu upaya tanggung jawab sosial BUMN adalah program kemitraan guna meningkatkan kemampuan UMKM dalam rangka mendorong kegiatan dan pertumbuhan ekonomi dengan terciptanya pemerataan pembangunan melalui perluasan lapangan kerja dan kesempatan berusaha. Menurut Ian Liontin kemitraan adalah salah satu cara untuk melakukan kegiatan bisnis untuk mencapai tujuan bersama antara pemasok dengan pelanggan yang berniaga (Raharjo, 2018).
PT Jasa Marga Surabaya Gempol penyelenggara program kemitraan berpedoman pada PER-02/MBU/7/2017 yang menjelaskan "bahwa untuk mendorong percepatan kemandirian usaha mikro dan kecil dalam rangka mewujudkan masyarakat adil, makmur dan merata maka perlu dilakukan pengembangan dan pemberdayaan usaha mikro dan kecil baik akses permodalan, manajemen maupun kegiatan lainnya" dengan kriteria usaha kecil yang dapat ikut serta dalam program kemitraan adalah sebagai berikut :

a. Memiliki kekayaan bersih paling banyak Rp 500.000.000,- (lima ratus juta rupiah), tidak termasuk tanah dan bangunan tempat usaha atau memiliki hasil penjualan tahunan paling banyak Rp 2.500.000.000,- (dua milyar lima ratus juta rupiah);

b. Milik Warga Negara Indonesia;

c. Berdiri sendiri, bukan merupakan anak perusahaan atau cabang perusahaan yang dimiliki, dikuasai, atau berafiliasi baik langsung maupun tidak langsung dengan Usaha Menengah atau Usaha Besar;

d. Berbentuk usaha orang perseorangan, badan usaha yang tidak berbadan hukum, atau badan usaha yang berbadan hukum, termasuk koperasi;

e. Mempunyai potensi dan prospek usaha untuk dikembangkan;

f. Telah melakukan kegiatan usaha minimal 6 (enam) bulan;

g. Tidak sedang menjadi MB perushaan lain ; dan

h. Belum memenuhi persyaratan perbankan aatu lembaga keuangan non bank.

Sumber dana program kemitraan diperoleh dari penyisihan laba perusahaan, jasa administrasi pinjaman/marjin/bagi hasil, bunga deposito dan/atau jasa giro dari dana program kemitraan setelah dikurangi beban operasional dan pelimpahan dana program kemitraan dari BUMN lain, jika ada. Besarnya jasa administrasi pinjaman dana program kemitraan sebesar 3\% (tiga persen) per tahun. Adapun sasaran pemberian bantuan program kemitraan oleh PT Jasa Marga Surabaya Gempol untuk masyarakat yang bertempat tinggal di wilayah Jawa Timur yang meliputi Kediri, Malang, Mojokerto, Pasuruan, Probolinggo, Surabaya, Lamongan dan Sidoarjo.

Bagi masyarakat yang berminat untuk mengikuti program kemitraan, dapat mengajukan 
proposal dan berkas persyaratan ke unit Community Development dan berikut mekanisme penyaluran pinjaman program kemitraan :

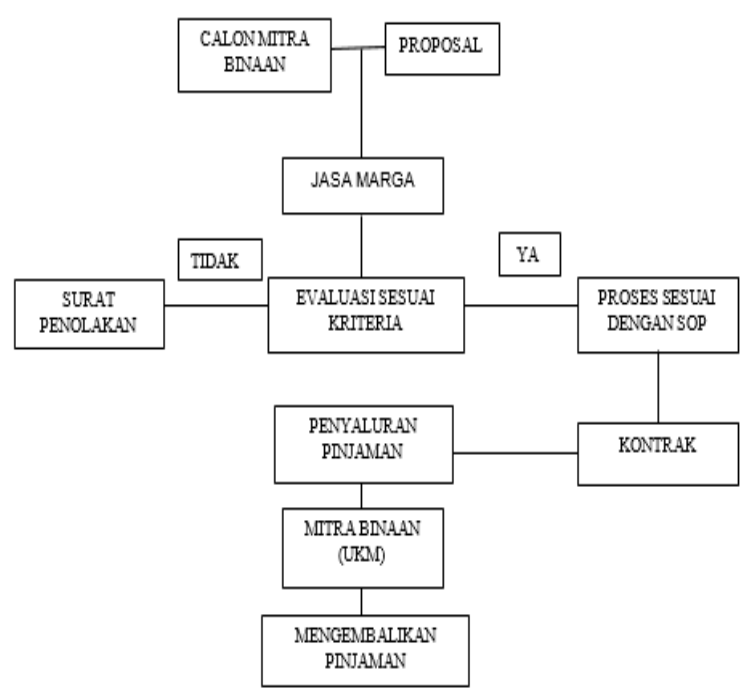

Gambar 1. Mekanisme Penyaluran Dana

PT Jasa Marga Surabaya Gempol tidak hanya memberikan bantuan permodalan tetapi juga bertanggung jawab melakukan pembinaan. Pelaksanaan kegiatan pembinaan meliputi bantuan modal usaha, program pelatihan manajemen usaha, pembinaan lapangan serta pameran bertujuan untuk pekermbangan kemampuan manajemen usaha dan terwujudnya pola pembinaan UMKM yang terintegrasi (Mudjiarto, 2019). Berikut data realisasi program kemitraan pada PT Jasa Marga Surabaya Gempol di tahun $2017-2020$.

Tabel 1. Realisasi Program Kemitraan

\begin{tabular}{|l|l|l|l|}
\hline NO & TAHUN & $\begin{array}{l}\text { PENYALURAN } \\
\text { PINJAMAN (Rp) }\end{array}$ & $\begin{array}{c}\text { JUMLAH } \\
\text { MITRA } \\
\text { BINAAN }\end{array}$ \\
\hline 1 & 2017 & 2.155 .000 .000 & 111 \\
\hline 2 & 2018 & 2.240 .000 .000 & 98 \\
\hline 3 & 2019 & 2.830 .000 .000 & 104 \\
\hline 4 & 2020 & 1.165 .000 .000 & 32 \\
\hline \multicolumn{2}{|l|}{ TOTAL } & 8.390 .000 .000 & 345 \\
\hline
\end{tabular}

Sumber : PT. Jasa Marga Surabaya-Gempol
Dari tabel diatas, penyaluran pinjaman oleh PT Jasa Marga Surabaya Gempol kepada mitra binaan pada tahun 2017- 2020 dengan jumlah nominal sebesar Rp8,39 miliar dan jumlah mitra binaan sebanyak 345 dengan bidang usaha yang dijalankan mitra binaan bervariasi mulai dari sektor industri, jasa, perdagangan, perikanan, perkebunan, pertanian dan peternakan.

Dari hasil wawancara yang dilakukan penulis dengan unit Community Development, pelaksanaan program kemitraan juga mempunyai hambatan dalam praktek kegiatannya yaitu adanya tunggakan atas kewajiban dari mitra binaan, ada beberapa faktor yang disebabkan yaitu kurangnya kesadaran sebagian mitra binaan didalam melaksanakan pembayaran kewajiban angsurannya, adanya situasi dan kondisi pada usaha mitra binaan yang mengalami penurunan sehingga memerlukan dana yang cukup untuk pengelolaan usahanya. Penanganan dalam hambatan tersebut PT. Jasa Marga Surabaya Gempol melakukan peringatan pada saat satu kali melakukan tunggakan tersebut, jika masih belum bisa untuk dibayarkan dari pihak perusahaan mendatangi di lokasi untuk melihat kondisi usaha mitra binaan. Jika dalam monitoring kondisi usaha mitra binaan benar mengalami penurunan dalam pemasukannya pihak perusahaan memberikan keringinan sampai 3 bulan.

\subsection{Kontribusi PT. Jasa Marga Tehadap UMKM Di Masa Pandemi Covid-19}

Dampak dari pandemi Covid-19 sejak Maret 2020 yang terjadi di Indoneisa tidak hanya pada sektor kesehatan saja, tetapi juga mempengaruhi sektor ekonomi. Salah satu contohnya yaitu memberi dampak kepada para pelaku UMKM yang disebabkan oleh menurunnya daya beli oleh masyarakat yang bisa mempengaruhi keberlangsungan UMKM. Hal ini tentu sangat mempengaruhi perekonomian nasional karena UMKM memiliki kontribusi besar dan krusial bagi negara. Kontribusi tersebut contohnya seperti UMKM dapat meratakan pembangunan ekonomi di seluruh Indonesia dan juga UMKM dapat memberi peluang bagi pelaku usaha untuk membuka lapangan kerja yang baru, maka hal itu dapat mengurangi kemiskinan dan pengangguran di Indonesia.

Kementerian BUMN memiliki komitmen untuk membantu dan mendukung para pelaku 
UMKM di masa pandemi Covid-19 karena korporasi atau perusahaan memiliki peranan yang cukup besar dalam pembangunan suatu daerah sebagai wujud dari implementasi tanggung jawab sosial, hal ini merupakan kontribusi suatu korporasi untuk turut serta membantu pemerintah untuk menggerakkan sekaligus mendorong perekonomian negeri dengan melakukan berbagai kegiatan yang meliputi pengembangan ekonomi, sosial dan juga perbaikan lingkungan yang diharapkan dapat mengurangi angka kemiskinan dan pengangguran. Pelaksanaan program tanggung jawab sosial perusahaan tidak hanya berfokus pada keuntungan bagi perusahaan saja, tetapi juga dimaksudkan untuk memberi kontribusi terbaik kepada masyarakat serta lingkungan dimana korporasi berada (Wambrauw, 2020). PT Jasa Marga sebagai salah satu perusahaan BUMN di Indonesia turut berkontribusi untuk UMKM di masa pandemi Covid-19 dan berkomitmen untuk terus ulurkan tangan kepada para pelaku UMKM dan mitra binaan.

Dilansir dari berita (www.jasamarga.com, 2020) PT. Jasa Marga tidak hanya mengedepankan atau mencari keuntungan-keuntungan atau profit perusahaan saja. PT. Jasa Marga juga memiliki tanggung jawab kepada komunitas-komunitas yang ada di sekitar perusahaan supaya kehadiran PT. Jasa Marga juga memiliki dampak positif bagi perusahaan maupun bagi seluruh masyarakat yang berada di sekitar lingkungan jalan tol Jasa Marga Group. PT Jasa Marga menyalurkan Rp1,4 miliar selama masa pandemi Covid-19 guna mendorong semangat para pengusaha agar terus bertahan dalam situasi seperti ini. Diketahui Terdapat total 24 UMKM dan 4 Mitra Binaan yang tersebar di beberapa provinsi yaitu di Provinsi Banten, DKI Jakarta, Jawa Barat, Jawa Timur, Sumatera Utara, Bali dan Kalimantan Timur.

PT. Jasa Marga juga memanfaatkan penggunaan jasa produksi UMKM dan Mitra Binaan sesuai dengan bidang usahanya, hal ini bertujuan untuk memenuhi perlengkapan berupa masker, hand sanitizer, Alat Pelindung Diri (APD) dan lainnya yang diberikan kepada masyarakat terdampak Covid-19. Dana yang didapat PT. Jasa Marga untuk digunakan membantu UMKM berasal sebagian dari dana Bina Lingkungan yang dikhususkan untuk para pelaku UMKM, dan sebagian lagi berasal dari realokasi Tunjangan Hari Raya (THR) Komisaris Direksi Jasa Marga Group.
Bantuan pinjaman dana yang diterima para pelaku UMKM oleh PT. Jasa Marga tentunya sangat membantu para pelaku UMKM untuk bertahan di tengah situasi yang sulit saat ini. Hal ini terbukti dengan terus berkembang nya UMKM, contohnya seperti pada tanggal 19 November - 22 November 2020 di Grand City Surabaya yaitu PT. Jasa Marga memilih 4 (empat) UMKM untuk mengikuti pameran INAPRO EXPO 2020 yaitu pameran yang diselenggarakan khusus bagi UMKM dengan tujuan mengenalkan produkproduk yang dijualkan oleh para pelaku UMKM. Disana ke-empat UMKM masing-masing menjual produknya sekaligus mengenalkan produkproduknya kepada orang yang berdatangan disana. Jenis usaha dari ke-empat UMKM tersebut berbeda-beda yaitu mulai dari kopi, kerajinan tas dan dompet, makanan, sampai kain batik. Pada saat hari terakhir pameran INAPRO EXPO 2020 PT. Jasa Marga mendapatkan penghargaan sebagai partisipan stand terbaik

\section{KESIMPULAN DAN SARAN \\ 4.1 Kesimpulan}

Tanggung jawab sosial perusahaan melalui program kemitraan merupakan pemberdayaan UMKM untuk tumbuh dan berkembang menjadi usaha yang tangguh, mandiri dan mendorong pertumbuhan ekonomi nasional serta perluasan kesempatan lapangan pekerjaan. Dalam program kemitraan, memberikan bantuan permodalan dengan besarnya jasa administrasi pinjaman sebesar $3 \%$ selain itu juga ada kegiatan pembinaan yang dilakukan dengan tujuan untuk pekermbangan kemampuan manajemen usaha. PT Jasa Marga menyalurkan Rp1,4 miliar selama masa pandemi Covid-19 guna mendorong semangat para pengusaha agar terus bertahan dalam situasi seperti ini terdapat total 24 UMKM dan 4 Mitra Binaan yang tersebar di Provinsi Banten, DKI Jakarta, Jawa Barat, Jawa Timur, Sumatera Utara, Bali dan Kalimantan Timur.

\subsection{Saran}

Dengan adanya pandemi Covid-19 ini, perlu adanya kontribusi,dukungan dan kerjasama dari Pemerintah, Pemerintah Daerah, Dunia Usaha, BUMN dan masyarakat untuk pemberdayaan UMKM agar terus maju dan bangkit dari situasi ini mengingat UMKM memeliki peran penting dan 
strategis dalam penyerapan tenaga kerja dan pembentukan produk domestik bruto di Indonesia.

\section{DAFTAR PUSTAKA}

UU No. 25 Tahun 2007 Tentang Penanaman Modal UU No. 40 Tahun 2007 Tentang Perseroan Terbatas

UU No. 20 Tahun 2008 Tentang Usaha Mikro, Kecil dan Menengah

PP No. 47 Tahun 2012 Tentang Tanggung Jawab Sosial Lingkungan Terbatas

PER-02/MBU/7/2017 Tentang Perubahan Kedua Atas Peraturan Menteri Badan Usaha Milik Negara Nomor Per-09/Mbu/07/ 2015 Tentang Program Kemitraan Dan Program Bina Lingkungan Badan Usaha Milik Negara

[1] Edward UP Nainggolan.2020.UMKM Bangkit, Ekonomi Indonesia

Terungkit.https://www.djkn.kemenkeu.go.id/arti kel/baca/13317/UMKM-Bangkit-EkonomiIndonesia-Terungkit.html. (24 Maret).

[2] Putra Sang Fajar.2020.Kolaborasi BUMN dan UMKM Solusi Hadapi Pandemi.https://www.kompasiana.com/cahkang kung/5f6c10d862e8037da6422c52/kolaborasibumn-.(24 Maret)

[3] Dwimawan Heru. Dukung Keberlangsungan Usaha, Jasa Marga Salurkan Rp 1,4 Miliar Kepada UMKM dan Mitra Binaan Selama Pandemi.https://www.jasamarga.com/public/id/ aktivitas/detail.aspx?title=Dukung\%20Keberlangs ungan\%20Usaha,\%20Jasa\%20Marga\%20Salurkan \%20Rp\%201,4\%20Miliar\%20Kepada\%20UMKM\%
20dan\%20Mitra\%20Binaan\%20Selama\%20Pande midan-umkm-solusi-hadapi-pandemi?page $=2 . \quad$ (5 April)

[4] Dwimawan Heru.2020. Dorong Keberlangsungan Usaha UMKM di Tengah Pandemi Covid-19, Jasa Marga Kembali Salurkan Rp3,5 Miliar Untuk Mitra Binaan.https://jasamarga.com/public/id/aktivitas Ldetail.aspx?title=Dorong\%20Keberlangsungan\% 20Usaha\%20UMKM\%20di\%20Tengah\%20Pande mi\%20Covid-

19,\%20Jasa\%20Marga\%20Kembali\%20Salurkan\% 20Rp3,5\%20Miliar\%20Untuk\%20Mitra\%20Binaan (5 April) 
